\title{
Effects of dietary lipid, vitamins and minerals on total amounts and redox status of glutathione and ubiquinone in tissues of Atlantic salmon (Salmo salar): a multivariate approach
}

\author{
Kristin Hamre $^{1}$, Bente E. Torstensen ${ }^{1}$, Amund Maage ${ }^{1}$, Rune Waagb $\varnothing^{1}$, Rolf K. Berge ${ }^{2}$ \\ and Sissel Albrektsen ${ }^{3,4}$ \\ ${ }^{1}$ National Institute of Nutrition and Seafood Research (NIFES), PO Box 176, Sentrum, N-5804 Bergen, Norway \\ ${ }^{2}$ Institute of Clinical Biology, Haukeland University Hospital, N-5021 Bergen, Norway \\ ${ }^{3}$ Ewos Innovation AS, Dirdal, Norway \\ ${ }^{4}$ Nofima Ingrediens, Kjerreidviken 16, N-5141 Fyllingsdalen, Norway
}

(Received 12 January 2010 - Revised 8 February 2010 - Accepted 24 February 2010 - First published online 14 June 2010)

\begin{abstract}
The hypothesis of the present study was that Atlantic salmon (Salmo salar) would respond to large variations in supplementation of dietary pro- and antioxidants, and marine lipid, with adjustment of the endogenously synthesised antioxidants, glutathione (GSH) and ubiquinone (UQ). An experiment with $2^{7-3}$ reduced factorial design (the number of cases reduced systematically from $2^{7}$ (full design) to $2^{4}$ (reduced design)) was conducted, where vitamins, minerals and lipid were supplemented in the diet at high and low levels. For the vitamins and minerals the high levels were chosen to be just below anticipated toxic levels and the low levels were just above the requirement (vitamin $\mathrm{C}, 30$ and $1000 \mathrm{mg} / \mathrm{kg}$; vitamin E, 70 and $430 \mathrm{mg} / \mathrm{kg}$; Fe, 70 and $1200 \mathrm{mg} / \mathrm{kg} ; \mathrm{Cu}, 8$ and $110 \mathrm{mg} / \mathrm{kg} ; \mathrm{Mn}, 12$ and $200 \mathrm{mg} / \mathrm{kg}$ ). For astaxanthin, the dietary levels were 10 and $50 \mathrm{mg} / \mathrm{kg}$ and for lipid, 150 and $330 \mathrm{~g} / \mathrm{kg}$. The experiment was started with post-smolts (148 (SD $17 \mathrm{~g}$ )) and lasted for 5 months. The only effect on GSH was a minor increase $(<10 \%)$ in total concentration in the liver in response to high dietary lipid. GSH redox state was not affected. UQ responded to dietary lipid, astaxanthin and vitamin $\mathrm{E}$, both with regard to total concentration and redox state. Except for an effect of Fe on plasma GSH, the trace elements and vitamin $\mathrm{C}$ had no effect on tissue levels and oxidation state of GSH and UQ. This shows that the endogenous redox state is quite robust with regard to variation of dietary pro- and antioxidants in Atlantic salmon.
\end{abstract}

Atlantic salmon: Pro-oxidants: Antioxidants: Vitamins: Minerals: Lipids

Atlantic salmon (Salmo salar) are fed diets with up to $400 \mathrm{~g}$ marine lipids per $\mathrm{kg}$, susceptible to lipid oxidation. Longchain PUFA, abundant in marine lipids, may oxidise in the feed or in the fish body and in both cases expose the fish to oxidative stress. Small amounts of reactive oxygen species are constantly generated through normal metabolism, by electron transport, phagocytotic activity and by certain enzymes (oxygenases, cytochrome P450) ${ }^{(1)}$. Reactive oxygen species are very reactive towards all biomolecules (lipids, proteins and nucleotides) and the reaction of reactive oxygen species with PUFA generates an auto-oxidation cycle where the product of one cycle is a free radical, which may react with a new PUFA ${ }^{(2)}$. Animals have built up extensive defence systems against in vivo peroxidation, consisting of antioxidant enzymes, endogenous antioxidants such as glutathione (GSH) and ubiquinone (UQ), and nutritional antioxidants such as vitamins $\mathrm{C}$ and $\mathrm{E}$ and carotenoids. Normally, this defence keeps in vivo oxidation at an extremely low level and small amounts of reactive oxygen species are even essential for regulation of cell growth and development and intracellular signalling ${ }^{(1,3)}$. Oxidative challenge can be encountered when the formation of free radicals exceeds the capacity of the antioxidant defence. Such a situation may develop after tissue injury or inflammation, as a result of exposure to pollution or oxidative drugs and nutrients, or during deficiency of antioxidant nutrients. In Atlantic salmon juveniles and parr, oxidative challenge and increased lipid peroxidation have been demonstrated after hyperoxia caused by supersaturation of the water with $\mathrm{O}_{2}^{(4)}$, after feeding high levels of $\mathrm{Cu}$ and $\mathrm{Cd}^{(5)}$ and during vitamin $\mathrm{E}$ deficiency ${ }^{(6)}$. Oxidative stress leads to damage of biomolecules, tissues and organs and subsequently to disease. It is important that fish are fed diets with an optimal balance of the antioxidant nutrients and that they have a well-functioning endogenous antioxidant defence to cope with oxidative challenges present in the fish farming situation.

Vitamin $\mathrm{E}$ is a chain-breaking antioxidant that reacts with the lipid peroxyl radical formed in auto-oxidation of PUFA to prevent it from reacting with a new PUFA, and rendering the tocopheroxyl radical. It is now well accepted 
that vitamin $\mathrm{C}$ recycles the tocopheroxyl radical situated in the interface between water and lipid at the membrane surface to reduced vitamin $\mathrm{E}^{(7,8)}$. Vitamin $\mathrm{C}$ also works as a radical scavenger in the water phase of the organism. The results of Mårtensson \& Meister ${ }^{(9)}$ demonstrate that the water-soluble endogenously synthesised antioxidant, GSH, reduces dehydroascorbic acid to ascorbate in newborn rats. In turn, oxidised GSH (GSSG) is reduced by NADPH produced in the pentose phosphate shunt ${ }^{(10)}$. Therefore, the recycling, and thereby sparing, of dietary antioxidants may ultimately be coupled to energy metabolism.

UQ is the only endogenously synthesised lipid with redox function in vertebrates and exhibits a broad-tissue as well as intracellular distribution ${ }^{(11)}$. It was first identified as part of the mitochondrial respiratory chain, but is now recognised to occur in all membrane types and acts as an antioxidant in its reduced form, ubiquinol ${ }^{(12)}$. In mitochondria, ubiquinol amplifies the antioxidant effect of vitamin E, apparently by regenerating the tocopheroxyl radical. UQ, in turn, can be reduced by succinate and $\mathrm{NADH}$ through the respiratory chain $^{(13)}$.

The requirements for dietary antioxidants such as vitamins $\mathrm{C}$ and $\mathrm{E}$ vary with the experimental conditions ${ }^{(6,14-16)}$. For vitamin $\mathrm{E}$ the reported requirements for salmonids vary between 5 and $60 \mathrm{mg} / \mathrm{kg}$, dependent on dietary lipid content and quality and on vitamin $C$ supplementation ${ }^{(6,17-19)}$. The vitamin $\mathrm{E}$ requirement may also be affected by astaxanthin and $\mathrm{Se}^{(15,20)}$ and possibly by other pro- and antioxidant nutrients. Further, vitamin $C$ requirement in Atlantic salmon seems to be slightly modulated by vitamin $\mathrm{E}$, where high dietary vitamin $\mathrm{E}$ increases the requirement ${ }^{(6)}$. This may be due to the regeneration of vitamin $\mathrm{E}$ by vitamin $\mathrm{C}^{(7,8)}$ which will consume reduced ascorbic acid.

Given the complex interactions of the antioxidant defence, it is difficult to compare results from different studies where one or two nutrients are investigated, since other nutrients may be supplemented at different levels and influence the results. In the present study, we used a multivariate approach to study effects and interactions between pro- and antioxidant nutrients and lipid on the nutrient-dependent and endogenous antioxidant defence. Seven different nutrients (vitamins $C$ and $\mathrm{E}$, astaxanthin, lipid, $\mathrm{Fe}, \mathrm{Cu}$ and $\mathrm{Mn}$ ) were given in high and low concentration according to a $2^{7-3}$ reduced factorial design $^{(21)}$. The low level of vitamins and minerals was chosen to be just above the minimum requirement, whereas the high level was below the anticipated toxic level, to cover the anticipated safe window of supplementation. For astaxanthin, the levels chosen were 10 and $50 \mathrm{mg} / \mathrm{kg}$, covering the range of increase in fillet astaxanthin concentration, whereas dietary lipid level was 150 and $320 \mathrm{~g} / \mathrm{kg}$. Several responses were monitored: growth, feed conversion and fillet quality $^{(22)}$, haematology, immune functions and antioxidant enzymes $^{(23)}$, cataract development ${ }^{(24)}$ and lipid metabolism $^{(25)}$. The present paper examines effects of the nutrient variation on the endogenous antioxidant defence.

\section{Materials and methods}

\section{Fish and diets}

The feeding experiment was carried out at Ewos Innovation AS in Dirdal, Norway, according to their fish-holding routines which are in accordance with the Animal Welfare Act of 12 December 1974 (no. 73, $\S 22$ and 30). Post-smolt Atlantic salmon, 148 (SD 17) g, were distributed into sixteen indoor $2.8 \mathrm{~m}^{3}$ tanks and stocked at 180 fish per tank. Sixteen different diets (for compositions, see Table 1) with two levels of vitamin $\mathrm{C}$, vitamin $\mathrm{E}$, astaxanthin, $\mathrm{Fe}, \mathrm{Cu}, \mathrm{Mn}$ and lipid were fed in excess using automatic feeders. The diets were produced by Ewos Innovation AS (Dirdal, Norway). The low-fat-diets were formulated to contain (per $\mathrm{kg}$ ): $450 \mathrm{~g}$ protein, $170 \mathrm{~g}$ fat, $65 \mathrm{~g}$ ash and $285 \mathrm{~g} \mathrm{~N}$-free extracts. The formulation of the high-fat diets (per $\mathrm{kg}$ ): was $450 \mathrm{~g}$ protein, $320 \mathrm{~g}$ fat, $65 \mathrm{~g}$ ash and $115 \mathrm{~g} \mathrm{~N}$-free extracts. The micronutrients were added at just above the minimum requirement and at a level that was anticipated to be below the toxic level: vitamin $\mathrm{E}$ (as all-rac- $\alpha$-tocopheryl acetate), 60 and $410 \mathrm{mg} / \mathrm{kg}$; vitamin C (as Stay- $\mathrm{C}^{\circledR}$ ), 30 and $2000 \mathrm{mg} / \mathrm{kg}$; Fe, 70 and $1200 \mathrm{mg} / \mathrm{kg} ; \mathrm{Cu}, 7$ and $100 \mathrm{mg} / \mathrm{kg} ; \mathrm{Mn}, 10$ and $200 \mathrm{mg} / \mathrm{kg}$. The minerals were added as water-saturated sulfates. Astaxanthin (as Carophyll Pink) was supplemented at 10 and $50 \mathrm{mg} / \mathrm{kg}$. Other vitamins and minerals were added according to the National Research Council ${ }^{(26)}$. Vitamins and astaxanthin were supplied by Hoffman-La Roche (Basle, Switzerland) and the minerals were from

Table 1. Main composition of the experimental diets

\begin{tabular}{|c|c|c|c|c|}
\hline \multirow[b]{2}{*}{ Feed ingredients $(\mathrm{g} / \mathrm{kg})$} & \multicolumn{2}{|c|}{ Low-lipid diets } & \multicolumn{2}{|c|}{ High-lipid diets } \\
\hline & $10 \mathrm{mg} / \mathrm{kg}$ astaxanthin & $50 \mathrm{mg} / \mathrm{kg}$ astaxanthin & $10 \mathrm{mg} / \mathrm{kg}$ astaxanthin & $50 \mathrm{mg} / \mathrm{kg}$ astaxanthin \\
\hline Astaxanthin (8\%) & 0.8 & 3.7 & 0.8 & 3.7 \\
\hline Capelin oil & 110 & 110 & 292 & 292 \\
\hline Binder & 0 & 0 & 45 & 42 \\
\hline Suprex maize & 307 & 304 & 40 & 40 \\
\hline LT fish meal & 460 & 460 & 500 & 500 \\
\hline Mineral mix $^{*}$ & 11.5 & 11.5 & 11.5 & 11.5 \\
\hline Vitamin $\mathrm{mix}^{*}$ & 10 & 10 & 10 & 10 \\
\hline Betaine $(78.6 \%)$ & 1.3 & 1.3 & 1.3 & 1.3 \\
\hline Soya protein concentrate & 100 & 100 & 100 & 100 \\
\hline
\end{tabular}


Table 2. Variable nutrient levels (1, high; -1 , low) in the experimental diets and analysed nutrient concentrations $(\mathrm{mg} / \mathrm{kg}$ or $\mathrm{g} / \mathrm{kg}$ ) of diets with high or low levels, respectively, of the nutrient in question

\begin{tabular}{|c|c|c|c|c|c|c|c|}
\hline Diet & Vitamin $E$ & Vitamin C & Astaxanthin & Lipid & $\mathrm{Fe}$ & $\mathrm{Cu}$ & $\mathrm{Mn}$ \\
\hline \multicolumn{8}{|c|}{ Variable nutrient levels } \\
\hline 1 & -1 & -1 & -1 & -1 & -1 & -1 & -1 \\
\hline 2 & 1 & -1 & -1 & -1 & 1 & -1 & 1 \\
\hline 3 & -1 & 1 & -1 & -1 & 1 & 1 & -1 \\
\hline 4 & 1 & 1 & -1 & -1 & -1 & 1 & 1 \\
\hline 5 & -1 & -1 & 1 & -1 & 1 & 1 & 1 \\
\hline 6 & 1 & -1 & 1 & -1 & -1 & 1 & -1 \\
\hline 7 & -1 & 1 & 1 & -1 & -1 & -1 & 1 \\
\hline 8 & 1 & 1 & 1 & -1 & 1 & -1 & -1 \\
\hline 9 & -1 & -1 & -1 & 1 & -1 & 1 & 1 \\
\hline 10 & 1 & -1 & -1 & 1 & 1 & 1 & -1 \\
\hline 11 & -1 & 1 & -1 & 1 & 1 & -1 & 1 \\
\hline 12 & 1 & 1 & -1 & 1 & -1 & -1 & -1 \\
\hline 13 & -1 & -1 & 1 & 1 & 1 & -1 & -1 \\
\hline 14 & 1 & -1 & 1 & 1 & -1 & -1 & 1 \\
\hline 15 & -1 & 1 & 1 & 1 & -1 & 1 & -1 \\
\hline 16 & 1 & 1 & 1 & 1 & 1 & 1 & 1 \\
\hline \multicolumn{8}{|c|}{ Analysed nutrient concentrations (mg/kg) } \\
\hline \multicolumn{8}{|c|}{ High (1) } \\
\hline Mean & 430 & 1940 & 48 & $320^{*}$ & 1230 & 110 & 198 \\
\hline SD & 20 & 130 & 2 & $20^{*}$ & 60 & 4 & 6 \\
\hline \multicolumn{8}{|c|}{$\operatorname{Low}(-1)$} \\
\hline Mean & 69 & 52 & 11 & $150^{\star}$ & 74 & 7 & 12 \\
\hline SD & 10 & 15 & 1 & $20^{*}$ & 10 & 1 & 2 \\
\hline
\end{tabular}

Merck (Darmstadt, Germany). Analysed levels of the dietary variables (Table 2) were close to the formulated ones.

During the experiment, mortalities were recorded and dead fish removed daily. Weight was determined by bulk weighing and subsequent counting of all the fish in each tank. The mean temperature, $\mathrm{O}_{2}$ level and salinity during the experimental period were $8.2 \pm 0.4^{\circ} \mathrm{C}, 12.6 \pm 0.7 \mathrm{mg} / \mathrm{l}$ and $29.2 \pm 1.2 \mathrm{~g} / \mathrm{l}$, respectively. The fish were exposed to continuous light.

\section{Experimental design}

The experiment was carried out as a $2^{7-3}$ reduced factorial design (Table 2). This implies that the seven independent dietary variables were added at two levels and that the number of dietary combinations (cases) was systematically reduced from $128\left(2^{7}\right)$ to sixteen $\left(2^{4}\right)$ according to Box et al. ${ }^{(27)}$. With a full factorial design it would be possible to calculate effects of the single nutrients (main effects) and all the interaction effects (IE), but with seven variables one would need 128 treatments. Reducing the design to $2^{7-3}$ and sixteen treatments gives loss of resolution, since the main effects and interactions overlap with one another. In this particular design, it is possible to calculate the main effects separated from each other and from the effects of two-factor interactions. There are three possible interpretations (overlap) of each two-factor interaction (Table 3) and the three-factor interactions overlap with the main effects. Three-factor interactions are usually small compared with main effects and two-factor interactions, which were considered in the present study. The advantage of this design is the possibility to screen a greater number of nutrients than in traditional designs, and to identify interactions between them. The use of one replicate per dietary treatment may be considered a disadvantage, but the fact that every nutrient level is replicated eight times increases the confidence of the study. A reduced factorial experiment is described by Langsrud et al. ${ }^{(28)}$, who evaluated the effects of varying six different ingredient and processing factors on the sensory quality of cheese. The experiment was set up as a $2^{6-2}$ reduced factorial design with sixteen treatments (cases). Sundberg's tutorial ${ }^{(29)}$ describes factorial designs in general and includes an example with a $2^{4-1}$ reduced factorial design.

\section{Sampling procedure}

Samples were taken from each batch of the diets and stored at $-20^{\circ} \mathrm{C}$. Fish were sampled at the start and after both 14 and 23 weeks. The fish were starved for $48 \mathrm{~h}$ before sampling. Sixteen randomly sampled fish from each tank were anaesthetised with metomidate $(7 \mathrm{~g} / \mathrm{l})$. Blood was drawn from the caudal vein into heparinised tubes, and centrifuged at $1000 \mathrm{~g}$ for $10 \mathrm{~min}$ at $4^{\circ} \mathrm{C}$ to separate blood cells and plasma. Plasma from the sixteen fish was pooled together and subsamples were frozen on dry ice. The fish were killed with a blow to

Table 3. Overlap pattern for two-factor interaction effects (IE) whereby each IE has three possible interpretations

\begin{tabular}{ll}
\hline $\mathrm{IE}$ & \multicolumn{1}{c}{ Overlapping dietary effects } \\
\hline $\mathrm{IE}_{1}$ & Vitamin E-vitamin C; astaxanthin-Fe; Cu-Mn \\
$\mathrm{IE}_{2}$ & Vitamin E-astaxanthin; vitamin C-Fe; lipid-Mn \\
$\mathrm{IE}_{3}$ & Vitamin E-lipid; astaxanthin-Mn; Fe-Cu \\
$\mathrm{IE}_{4}$ & Vitamin E-Fe; vitamin C-astaxanthin; lipid-Cu \\
$\mathrm{IE}_{5}$ & Vitamin E-Cu; lipid-Fe; vitamin C-Mn \\
$\mathrm{IE}_{6}$ & Vitamin E-Mn, astaxanthin-lipid; vitamin C-Cu \\
$\mathrm{IE}_{7}$ & Vitamin C-lipid; astaxanthin-Cu; Fe-Mn \\
\hline
\end{tabular}


the head, and liver and the whole fillet were removed. The tissue samples from the sixteen fish per tank were pooled together, homogenised on ice and frozen as subsamples on dry ice. Samples were stored at $-80^{\circ} \mathrm{C}$.

\section{Chemical analyses}

$\alpha$-Tocopherol was analysed by HPLC by the method of Lie et al. ${ }^{(30)}$. Total ascorbic acid was also analysed by HPLC according to Mæland \& Waagb $\varnothing^{(31)}$. The feed samples were hydrolysed with phosphatase before extraction. Astaxanthin was analysed according to Torrissen ${ }^{(32)}$ and total lipid, gravimetrically, according to Lie et $a l .{ }^{(33)}$. The analyses of dietary $\mathrm{Fe}, \mathrm{Cu}$ and $\mathrm{Mn}$ were carried out using flame atomic absorption as described by Liaset $e t a l^{(34)}$. Thiobarbituric acid-reactive substances (detection limit $1.17 \mathrm{nmol} / \mathrm{g}$ wet weight) were analysed according to Hamre et al. ${ }^{(35)}$ and GSH by the method of Svardal et al. ${ }^{(36)}$.

A method modified from Lang et al. ${ }^{(37)}$ and Podda et al. ${ }^{(38)}$ was applied for analyses of UQ and ubiquinol. A $0 \cdot 05-0 \cdot 1 \mathrm{~g}$ homogenised sample was dissolved in $1 \mathrm{ml}$ distilled water, $1 \mathrm{ml} 0 \cdot 2 \mathrm{M}-\mathrm{SDS}$ and $2 \mathrm{ml}$ ethanol in screw-capped $10 \mathrm{ml}$ glass tubes and extracted three times with $3 \mathrm{ml}$ hexane. The extracts were pooled, evaporated to dryness under $\mathrm{N}_{2}$ (room temperature) and dissolved in mobile phase, before injection into the HPLC. The HPLC system consisted of a pump (L-7100; Merck-Hitachi, Darmstadt, Germany) an auto-injector (AS3000; Spectra System, San Jose, CA, USA), a UV detector (UV1000; Spectra System) and a LC-18 analytical column $(4.6 \times 150 \mathrm{~mm} ; 3 \mu \mathrm{m}$ particle size; Supelco, Bellefonte, PA, USA). The mobile phase consisted of $85 \%$ methanol and $15 \%$ tetrahydrofuran, flow rate was $1.5 \mathrm{ml} / \mathrm{min}$ and detection was performed at $290 \mathrm{~nm}$ (ubiquinol) between 0 and $6.5 \mathrm{~min}$ and at $275 \mathrm{~nm}$ (UQ) from $6.5 \mathrm{~min}$. Quantification was performed with external standards for UQ and a correction factor for ubiquinol of $0 \cdot 28$, based on the extinction coefficients $(1 \%$; $1 \mathrm{~cm}) \mathrm{E}_{\mathrm{UQ} 275 \mathrm{~nm}}=165$ and $\mathrm{E}_{\text {ubiquinol290nm }}=46^{(38)}$. Recoveries of UQ standard from liver and plasma were 99 (SD 7) and 102 (SD 4) $\%$, respectively, and linearity was found in the area $2 \mathrm{ng}-20 \mu \mathrm{g}$ UQ injected into the column. Muscle samples gave peaks in the chromatogram which overlapped with UQ. Therefore, muscle was not analysed for this compound.

\section{Statistics}

The software package Statistica for Windows version 4.5 (StatSoft Inc., Tulsa, OK, USA, 1993) was used for the statistical analyses. Significant effects of the dietary parameters or their two-factor interactions were calculated using multiple linear regression. Each response was calculated separately and only response models where all effects were significant were accepted as valid.

\section{Results}

Results on growth, survival and feed conversion have been reported by Hamre et $a l^{(22)}$. The average specific growth rate was $0.92 \% / d$ with a positive effect of high dietary lipid $\left(P<10^{-6}\right)$, increasing the final weight by $12 \%$, and a slight negative effect of high dietary $\mathrm{Fe}(P<0 \cdot 05)$. The average feed conversion rate was 1.07 and high dietary lipid reduced feed conversion by $0 \cdot 14\left(P<10^{-5}\right)$. There were between zero and two mortalities per tank. The most important factor for determining astaxanthin concentration in muscle was dietary astaxanthin $\left(P<10^{-4}\right)$, but there was also a positive effect of lipid in week $14(P=0.0003)$. Astaxanthin in the liver was affected by dietary astaxanthin, lipid, vitamin E, Fe and Mn. Muscle, but not liver, lipid was increased by high dietary lipid $\left(P<10^{-6}\right)$. In the liver, the lipid level was affected by vitamin $\mathrm{E}$ and $\mathrm{Mn}$ but the magnitude of the effects was less than $10 \%(22)$

Ascorbic acid concentration in liver, plasma and fillet (Table 4) was mainly influenced by dietary vitamin C, as none of the other dietary variables gave consistent responses or responses that were higher than $10 \%$ of the mean. Vitamin $\mathrm{C}$ had a profound effect on plasma and tissue concentrations of ascorbic acid $\left(P<10^{-6}\right)$ and the models were very well correlated with the data $\left(R^{2} 0 \cdot 84-1 \cdot 00\right)$.

$\alpha$-Tocopherol in liver, plasma and fillet (Table 4) was positively affected by high dietary vitamin $\mathrm{E}\left(P<10^{-5}\right)$ and negatively affected by high dietary lipid $(P<0.006)$. In liver and fillet, there was a negative effect of $\mathrm{IE}_{3} \quad(P \leq 0 \cdot 001$; Table 3) on $\alpha$-tocopherol concentration. In addition, high dietary Mn gave an increased concentration of $\alpha$-tocopherol in fillet in week $14\left(P<10^{-4}\right)$. Vitamin A (Table 4) in liver in week 23 was positively and profoundly affected by high dietary lipid $\left(P<10^{-6}\right)$. The models for plasma and tissue $\alpha$-tocopherol and vitamin A fitted the data well $\left(R^{2} 0 \cdot 83-1 \cdot 00\right)$.

Plasma and liver $\mathrm{Fe}$ was increased by high dietary $\mathrm{Fe}$ $(P<0.04)$, while there was no effect of the other varied nutrients on tissue Fe levels (Table 4). No nutritional effects were seen on the concentration of $\mathrm{Fe}$ in bone. There were no effects of the dietary variables on tissue levels of $\mathrm{Cu}$. Mn levels in liver, plasma and bone were increased by high dietary $\mathrm{Mn}$ $(P=0.04-0 \cdot 002)$, and by high dietary lipid $(P=0.04-0.01)$, except in plasma in week 14. High dietary vitamin $C$ decreased Mn concentration in plasma in week $23(P=0.02)$.

Tissue and plasma concentrations of GSH (Table 4) were only marginally affected by the dietary variation. Liver total concentration of GSH was positively influenced by high dietary lipid $(P<0.001)$ and negatively by $\operatorname{IE}_{3}(P<0.004)$ and the fit between models and data was good $\left(R^{2} 0.95-1 \cdot 00\right)$. In plasma, $\mathrm{IE}_{3}$ decreased the fraction of reduced $\mathrm{GSH}$ at both samplings $(P<0 \cdot 05)$, whereas the fraction was increased by high dietary vitamin $\mathrm{E}(P=0.005)$ and reduced by high dietary Fe $(P=0.007)$ in week 23 . There were no consistent effects, or effects exceeding $10 \%$ of the mean, on liver percentage of reduced GSH, plasma total concentration of GSH or muscle GSH.

UQ (Table 4) in liver was influenced by dietary vitamin E, astaxanthin and lipid. High dietary lipid led to an increase, both in total concentration $\left(P<10^{-6}\right)$ and in fraction, of reduced ubiquinol $\left(P \leq 10^{-6}\right)$ in the liver. High dietary vitamin E gave slightly increased total concentration (NS in week 14 and $P=0.005$ in week 23) and a slightly smaller fraction of reduced ubiquinol $(P \leq 0 \cdot 002)$, while the opposite was true for high dietary astaxanthin $(P \leq 0.002)$. The net effect of vitamin $\mathrm{E}$ and astaxanthin on liver total concentration and fraction of reduced UQ was a similar concentration of reduced ubiquinol. There was a good fit between models and data concerning liver UQ $\left(R^{2} 0 \cdot 88-0 \cdot 98\right)$. All UQ in plasma was oxidised. The total plasma concentration was increased by high dietary lipid (NS in week 14 and $P=0.04$ in week 23) and decreased by 
Table 4. Biological effects of pro- and antioxidants and lipid on plasma and tissue ascorbic acid, $\alpha$-tocopherol, vitamin A, iron, copper, manganese, glutathione and ubiquinone in Atlantic salmon (Salmo salar) fed the experimental diets for 14 or 23 weeks*

\begin{tabular}{|c|c|c|}
\hline Response (week) & Response model $(\mathrm{Y})$ & $R^{2}$ \\
\hline \multicolumn{3}{|l|}{ Ascorbic acid ( $\mu \mathrm{g} / \mathrm{g}$ wet weight) } \\
\hline Liver (14) & $Y=156+66$ vitamin $C$ & 1.00 \\
\hline Liver (23) & $Y=193+54$ vitamin $C$ & 0.84 \\
\hline Plasma (14) & $Y=24+16$ vitamin $C$ & 1.00 \\
\hline Plasma (23) & $Y=22+16$ vitamin $C$ & 0.99 \\
\hline Fillet (14) & $Y=18+7$ vitamin $C$ & 0.97 \\
\hline Fillet (23) & $Y=23+8$ vitamin $C$ & 0.98 \\
\hline \multicolumn{3}{|l|}{$\alpha$-Tocopherol ( $\mu \mathrm{g} / \mathrm{g}$ wet weight) } \\
\hline Liver (14) & $\mathrm{Y}=970+780$ vitamin $\mathrm{E}-400$ lipid $-320 \mathrm{IE}_{3}$ & 0.94 \\
\hline Liver (23) & $Y=1670+1450$ vitamin $E-480$ lipid $-380 I_{3}$ & 1.00 \\
\hline Plasma (14) & $Y=42+15$ vitamin $E-6$ lipid & 0.83 \\
\hline Plasma (23) & $\mathrm{Y}=62+25$ vitamin $\mathrm{E}-2$ lipid & 1.00 \\
\hline Fillet (14) & $\mathrm{Y}=13.3+4.0$ vitamin $\mathrm{E}-1.8 \mathrm{lipid}+1.4 \mathrm{Mn}-1.5 \mathrm{IE}_{3}$ & 0.98 \\
\hline Fillet (23) & $\mathrm{Y}=21.5+9.1$ vitamin $\mathrm{E}-2.6 \mathrm{lipid}-1.9 \mathrm{IE}_{3}$ & 0.97 \\
\hline \multicolumn{3}{|l|}{ Vitamin A ( $\mu \mathrm{g} / \mathrm{g}$ wet weight) } \\
\hline Liver (23) & $Y=220+52$ lipid & 0.96 \\
\hline \multicolumn{3}{|l|}{$\mathrm{Fe}(\mu \mathrm{g} / \mathrm{g}$ wet weight) } \\
\hline Liver (14) & $Y=96+22 \mathrm{Fe}$ & 0.79 \\
\hline Liver (23) & $Y=116+22 \mathrm{Fe}$ & 0.75 \\
\hline Plasma (14) & $Y=1.22+0.13 \mathrm{Fe}$ & 0.26 \\
\hline Plasma (23) & $Y=1.15+0.22 \mathrm{Fe}$ & 0.74 \\
\hline Bone (14) & $Y=18 \cdot 2$ & NS \\
\hline Bone (23) & $Y=16 \cdot 0$ & NS \\
\hline \multicolumn{3}{|l|}{$\mathrm{Cu}(\mu \mathrm{g} / \mathrm{g}$ wet weight) } \\
\hline Liver (14) & $Y=56$ & NS \\
\hline Liver (23) & $Y=76$ & NS \\
\hline Plasma (14) & $Y=0.83$ & NS \\
\hline Plasma (23) & $Y=1.05$ & NS \\
\hline Bone (14) & $Y=4.9$ & NS \\
\hline Bone (23) & $Y=4.6$ & NS \\
\hline \multicolumn{3}{|l|}{$\mathrm{Mn}$ ( $\mu \mathrm{g} / \mathrm{g}$ wet weight) } \\
\hline Liver (14) & $Y=1.36+0.06$ lipid $+0.09 \mathrm{Mn}$ & 0.78 \\
\hline Liver (23) & $Y=1.5+0.07$ lipid $+0.07 \mathrm{Mn}$ & 0.70 \\
\hline Plasma (14) & $Y=0.052$ & NS \\
\hline Plasma (23) & $Y=0.093-0.012$ vitamin $C+0.019$ lipid $+0.037 \mathrm{Mn}$ & 0.92 \\
\hline Bone (14) & $Y=30.3+2.4$ lipid $+8.8 \mathrm{Mn}$ & 0.93 \\
\hline Bone (23) & $Y=37+5$ lipid $+12 M n$ & 0.97 \\
\hline \multicolumn{3}{|c|}{ Glutathione $(\mu \mathrm{mol} / \mathrm{g}$ wet weight or $\%$ reduced $)$} \\
\hline Liver (14) total concentration & $Y=5.73+0.095$ lipid $+0.043 I_{3}$ & 1.00 \\
\hline Liver (23) total concentration & $Y=6.69+0.33$ lipid $+0.13 \mathrm{IE}_{3}$ & 0.95 \\
\hline Liver (14) \% reduced & $\mathrm{Y}=94$ & NS \\
\hline Liver $(23) \%$ reduced & $\mathrm{Y}=89$ & $0.40 \dagger$ \\
\hline Plasma (14) total concentration & $Y=0.064$ & NS \\
\hline Plasma (23) total concentration & $Y=0.061$ & $0.83 \dagger$ \\
\hline Plasma (14) \% reduced & $Y=21-2 \cdot 2 I_{3}$ & 0.20 \\
\hline Plasma (23) \% reduced & $Y=26+2.9$ vitamin $E-2.8 \mathrm{Fe}-1.9 \mathrm{IE}_{3}$ & 0.65 \\
\hline Muscle (14) total concentration & $Y=0.64$ & $0.49 \dagger$ \\
\hline Muscle (23) total concentration & $Y=0.65$ & $0.28 \dagger$ \\
\hline Muscle (14) \% reduced & $Y=88$ & NS \\
\hline Muscle $(23) \%$ reduced & $\mathrm{Y}=89$ & $0.61 \dagger$ \\
\hline \multicolumn{3}{|c|}{ Ubiquinone $(\mu \mathrm{g} / \mathrm{g}$ wet weight or $\%$ reduced $)$} \\
\hline Liver (14) total concentration & $Y=75+2$ vitamin $E-3$ astaxanthin +11 lipid & 0.88 \\
\hline Liver (23) total concentration & $Y=113+4$ vitamin $E-5$ astaxanthin +27 lipid & 0.98 \\
\hline Liver (14) \% reduced & $Y=54-2.5$ vitamin $E+2.1$ astaxanthin +8.4 lipid & 0.93 \\
\hline Liver $(23) \%$ reduced & $Y=67-4.2$ vitamin $E+3.4$ astaxanthin +8.8 lipid & 0.90 \\
\hline Plasmał (14) total concentration & $Y=0.21-0.05$ astaxanthin +0.02 lipid & 0.69 \\
\hline Plasma $\neq$ (23) total concentration & $Y=0.38-0.10$ astaxanthin +0.02 lipid & 0.97 \\
\hline
\end{tabular}

IE, interaction effect; NS, no significant effects of nutrients.

* The response models were obtained by multiple linear regression using the varied nutrients and their IE (see Table 3 ) as independent variables (value 1 or -1 ). Models and effects were considered significant at $P<0 \cdot 05$, but only effects higher than $10 \%$ of the mean or effects that were repeated at both samplings (weeks 14 and 23 ) are included in the Table.

$\dagger$ There were minor effects $(<10 \%$ of mean) which were not included in the Table.

$\ddagger$ Ubiquinone in plasma was $100 \%$ oxidised. 
high dietary astaxanthin $(P \leq 0.002)$. In week 23 there was a good fit between model and data for plasma UQ concentration $\left(R^{2} 0.97\right)$.

The concentration of thiobarbituric acid-reactive substances in liver was $3.5 \mathrm{nmol} / \mathrm{g}$ wet weight and not affected by the dietary treatments while the fillet concentrations were below the detection limit of the method.

\section{Discussion}

The present study shows that the total concentration and redox state of GSH in Atlantic salmon tissues were only marginally affected by the high ranges of variations in diet composition. High compared with low dietary lipid level gave a difference in total GSH in the liver of maximally $10 \%$. In addition, $\mathrm{IE}_{3}$ had an effect of increasing total liver GSH from low to high by $4 \% . \mathrm{IE}_{3}$ is the interaction between lipid and vitamin $\mathrm{E}$, between astaxanthin and $\mathrm{Mn}$ or between $\mathrm{Fe}$ and $\mathrm{Cu}$. Since two-factor interactions are normally higher for high than for low main effects ${ }^{(29)}, \mathrm{IE}_{3}$ in this case is probably the interaction of lipid with vitamin E. There were also some effects on percentage of reduced GSH in plasma, where the difference between diets high or low in vitamin $\mathrm{E}$ was $22 \%$, and astaxanthin and $\mathrm{IE}_{3}$ changed the percentage of reduced GSH by -22 and $-15 \%$, respectively. There were no further effects of diet variation on tissue and plasma GSH, including GSH in muscle. The total concentration of GSH in the liver was approximately ten times that in muscle and 100 times that in plasma.

The dietary effects on UQ were both more diverse and of greater magnitude than those on GSH. Dietary lipid had the most profound effect, increasing the total concentration of UQ in the liver by $29-48 \%$ and in the plasma by $20 \%$. The redox state of UQ in the liver responded $26-31 \%$ on high compared with low lipid. Vitamin E had a slight positive effect on total concentration of UQ and a slight negative effect on percentage of reduced UQ in the liver, while the opposite was true for astaxanthin. A high level of astaxanthin also lowered plasma total concentration of UQ. UQ in muscle was not determined due to problems with overlapping peaks in the chromatogram. Thus, lipid and the lipid-soluble antioxidants vitamin $\mathrm{E}$ and astaxanthin affected GSH and UQ status in tissues and plasma of Atlantic salmon, while vitamin $\mathrm{C}, \mathrm{Fe}$, $\mathrm{Cu}$ and $\mathrm{Mn}$ had no effect on these variables. The dietary variation had no effect on liver thiobarbituric acid-reactive substances, and the fillet level did not increase to above the detection limit of the method in response to any diet. Therefore, the fish do not seem to have been subject to adverse oxidative stress.

According to the hypothesis of Hoffman et al. ${ }^{(39)}$, the GSSG:GSH ratio has a great impact on the redox potential of the cell, since GSH is present at very high concentrations, i.e. $1-10 \mathrm{~mm}$. Further, the redox potential regulates phosphorylation and dephosphorylation of proteins involved in cell-cycle regulation; in the reduced state these proteins are phosphorylated and the cells proliferate, while in the oxidised state, the proteins are dephosphorylated and the cells are at rest. Kemp et al. ${ }^{(40)}$ propose that the thioredoxin system and protein cysteine/cystine couples also participate in the regulation of the cell redox potential and that different cell compartments have different redox regulators, although the concentrations of these compounds are only in the range of $50 \mu \mathrm{M}^{(41)}$. Mechanisms involved in post-transcriptional redox regulation of proteins are the reversible formation of disulfide bridges internally in protein, between subunits or between separate proteins and glutathionation of protein cysteine residues. This causes conformational changes in the proteins ${ }^{(42)}$, which may lead to phosphorylation-dephosphorylation ${ }^{(39)}$ or other changes in activity. Cellular concentrations of GSH are regulated through two principal pathways, de novo synthesis of $\mathrm{GSH}$, where the rate-limiting enzyme is glytamyl cysteine ligase (also known as $\gamma$-glutamylcysteine synthetase), and by reduction of GSSG by GSH reductase. Glytamyl cysteine ligase is stimulated by oxidative stress and GSH depletion and inhibited by high concentrations of $\mathrm{GSH}^{(43)}$. Both glytamyl cysteine ligase and GSH reductase were induced by ischaemia-reperfusion of rat heart, which is known to be accompanied by increased oxidative stress ${ }^{(44)}$.

The mechanism by which high dietary lipid increased total GSH and UQ concentration in the liver of Atlantic salmon in the present study is not known, but one could speculate on at least two mechanisms. The lipid in salmon feeds has a high level of $n-3$ PUFA; in the present study $n-3$ fatty acids contributed to $20 \%$ of total dietary fatty acids ${ }^{(25)}$. Increasing the dietary level of this lipid source may have led to increased oxidative stress and a response in the fish to increase the oxidant defence, for example, by stimulated synthesis of GSH and UQ. Another possibility is that increased dietary fat would contribute with more reducing equivalents into the cell, rendering it in a more reduced state. However, the GSSG:GSH ratio was not altered by the dietary treatments, i.e. dietary lipid appears not to have altered the redox status of the cytosol of the liver cells. UQ is present in both cellular and organelle membranes, and most abundant in Golgi vesicles, lysosomes and mitochondria ${ }^{(11)}$. Dietary lipid altered the ratio between oxidised and reduced UQ, indicating that the redox potential of the membranes was altered. Another possible explanation for the higher UQ in the livers of the high lipid groups is that increasing dietary lipid and hence increased levels of EPA may lead to increasing amounts of hepatic mitochondria as has been shown by Vegusdal et al. ${ }^{(45)}$ to occur in Atlantic salmon hepatocytes stimulated with EPA.

The effects of vitamin E and astaxanthin on UQ concentration and redox state in the liver and plasma of Atlantic salmon were minor, and the gain of total UQ by high vitamin $\mathrm{E}$ in the liver was compensated by a loss of reduced UQ, and vice versa for astaxanthin. Vitamin $\mathrm{E}$ also increased total superoxide dismutase in the muscle and liver of Atlantic salmon, while astaxanthin reduced catalase activity in both tissues $^{(23)}$. The mechanisms of these impacts are not known at present.

The low dietary levels of vitamins and minerals were chosen to be just above the minimal requirement of Atlantic salmon, while the high levels were below anticipated toxic levels. The supplementation was therefore within what may be considered a safe window and this may be the reason that the minerals and vitamin $\mathrm{C}$ did not affect GSH and UQ homeostasis, which is probably tightly regulated. In the present study, the dietary variation had no effect on tissue concentrations of $\mathrm{Cu}$. High compared with low $\mathrm{Fe}$ increased plasma and liver concentrations of $\mathrm{Fe}$ by approximately 
$40 \%$, with no further effects of the other nutrients. Mn concentrations were increased in the liver by $9-13 \%$, in plasma week 23 by $80 \%$, and in bone by $58-65 \%$, in groups with high compared with low dietary Mn. High dietary lipid also caused considerably increased Mn concentrations, while vitamin $C$ had a negative effect on plasma Mn in week 23 .

Tissue levels of the three trace elements studied are to a certain extent regulated at the intestinal level, at least when added in the inorganic form. This is especially true for $\mathrm{Cu}$. The findings of the present study are in line with Berntssen et al. ${ }^{(46)}$, where only minor tissue elevations of $\mathrm{Cu}$ were shown with high dietary levels of the element. This is because the element is strongly bound to intestinal tissue and excreted through apoptosis $^{(47)}$. One would expect a minor increase in hepatic $\mathrm{Fe}$ with high dietary levels of inorganic $\mathrm{Fe}$ in accordance with Andersen et $a l^{\left({ }^{(4)}\right.}$ and as was shown in the present study. A certain amount of $\mathrm{Mn}$ is absorbed and transported to the vertebra in line with findings from requirement studies $^{(49)}$. Vitamin $\mathrm{C}$ concentrations in Atlantic salmon tissues increase in response to increasing dietary vitamin $\mathrm{C}^{(6)}$, as was the case in the present study. None of the other nutrients affected vitamin $\mathrm{C}$ status in plasma, liver and muscle of salmon. In view of the uptake kinetics and retention of vitamin $\mathrm{C}$ and the trace elements, one would expect that $\mathrm{Cu}$ would have no effect on GSH and UQ, while Fe, Mn and vitamin $\mathrm{C}$ may have been expected to have an effect due to their varying tissue concentrations and participation in the defence against oxidative stress. However, it is possible that the antioxidant enzymes superoxide dismutase and catalase were already saturated with $\mathrm{Mn}$ and $\mathrm{Fe}$ at the minimum dietary requirements. This is supported by the fact that the activities of superoxide dismutase in muscle and liver were not affected by $\mathrm{Mn}$, while catalase activity was either not affected or reduced, as shown by Lygren et al. ${ }^{(4)}$. Vitamin C is directly coupled to $\mathrm{GSH}$ in reactions regenerating oxidised antioxidants, such as vitamin $\mathrm{E}^{(9)}$, and it is therefore surprising that ascorbate had no effect on GSH status. Plasma and tissue concentrations of vitamin $\mathrm{E}^{(6)}$, astaxanthin ${ }^{(22,50)}$ and lipid ${ }^{(22,25)}$ increase with increasing dietary levels of these nutrients. In the present study, high dietary lipid also caused a decrease in $\alpha$-tocopherol concentrations in plasma, muscle and liver. Therefore, the basis for the effects of lipid and lipid-soluble nutrients on GSH and UQ status was probably changes in plasma and tissue concentrations.

An interesting feature of the present experiment is that increases in the total concentrations of GSH and UQ and in the ratio of reduced to oxidised UQ in Atlantic salmon in response to high dietary lipid correlated with an increase in growth and condition factor and a decrease in the rate of feed consumption to body weight increase. A decrease in redox potential of tissues is known to occur in proliferating cells ${ }^{(39,40)}$, and cell proliferation may be correlated with increased energy supply and growth. Atlantic salmon has the ability to increase growth with increasing levels of dietary lipid to above $40 \%{ }^{(51)}$, as long as the protein requirement is covered. This is in contrast to many other fish species such as Atlantic cod and Atlantic halibut which do not increase growth in response to high lipid levels ${ }^{(52,53)}$.

In summary, vitamin $\mathrm{C}$, vitamin $\mathrm{E}$, astaxanthin, lipid, Fe, $\mathrm{Cu}$ and $\mathrm{Mn}$ were supplemented at high or low levels in the diet for Atlantic salmon in the present experiment, covering the safe window of supplementation for vitamins and minerals and the widow of supplementation in commercial aquaculture for astaxanthin and lipid. These variations in the diet had little impact on the total concentrations and redox status of GSH, where the only reproducible effect was that of high dietary lipid having a minor effect of liver total GSH concentration. The magnitude and diversification of dietary effects were greater on UQ, which responded to dietary lipid, astaxanthin and vitamin E, both with regard to total concentration and redox status. This shows that the endogenous redox regulation is quite stable and only to a limited extent responds to dietary manipulation of pro- and antioxidant nutrients. Dietary lipid and the lipid-soluble nutrients had the most prominent impacts and the lipid-soluble UQ was more sensitive to dietary changes than the water-soluble GSH.

\section{Acknowledgements}

The present study was funded by the Research Council of Norway (project no. 112317/120) and by NorAqua Innovation (now EWOS Innovation), Dirdal, Norway.

All authors except R. K. B. participated in the planning of the experiment; S. A. had the main responsibility for running the fish experiment; K. H., B. E. T., R. W. and S. A. participated in sampling. K. H., R. W. and A. M. were responsible for different parts of the analytical work. The preparation of the paper was headed by K. H. with inputs from the other authors.

There are no conflicts of interests connected to the present publication.

\section{References}

1. Rice-Evans C \& Burdon R (1993) Free radical-lipid interactions and their pathological consequences. Prog Lipid Res 32, 71-110.

2. Frankel EN (1998) Lipid Oxidation. Dundee, UK: The Oily Press Ltd.

3. Nordberg J \& Arner ESJ (2001) Reactive oxygen species, antioxidants, and the mammalian thioredoxin system. Free Radic Biol Med 31, 1287-1312.

4. Lygren B, Hamre K \& Waagbø R (2000) Effect of induced hyperoxia on the antioxidant status of Atlantic salmon Salmo salar L. fed three different levels of dietary vitamin E. Aquac Res 31, 401-407.

5. Berntssen MHG, Lundeby A-K \& Hamre K (2000) Tissue lipid peroxidative responses in Atlantic salmon (Salmo salar L.). parr fed high levels of dietary copper and cadmium. Fish Physiol Biochem 23, 35-48.

6. Hamre K, Berge RK, Waagbø R, et al. (1997) Vitamins C and E interact in juvenile Atlantic salmon (Salmo salar, L.). Free Radic Biol Med 22, 137-149.

7. Tappel AL (1962) Vitamin E as the biological lipid antioxidant. Vitam Horm 20, 493-510.

8. Packer JE, Slater TF \& Willson RL (1979) Direct observation of a free radical interaction between vitamin $\mathrm{E}$ and vitamin $\mathrm{C}$. Nature 278, 737-738.

9. Mårtensson J \& Meister A (1991) Glutathione deficiency decreases tissue ascorbate levels in newborn rats: ascorbate spares glutathione and protects. Proc Natl Acad Sci U S A 88, 4656-4660

10. Meister A (1994) Glutathione-ascorbic acid antioxidant systems in animals. J Biol Chem 269, 9397-9400. 
11. Dallner G \& Sindelar PJ (2000) Regulation of ubiquinone metabolism. Free Radic Biol Med 29, 285-294.

12. Ernster L \& Dallner G (1995) Biochemical, physiologiscal and medical aspects of ubiquinone function. Biochem Biophys Acta 1271, 195-204.

13. Maguire JJ, Kagan V, Ackrell BAC, et al. (1992) Succinateubiquinone reductase linked recycling of $\alpha$-tocopherol in reconstituted systems and mitochondria: requirement for reduced ubiquinone. Arch Biochem Biophys 292, 47-53.

14. Poston HA, Combs GFJ \& Leibovitz L (1976) Vitamin E and selenium interrelations in the diet of Atlantic salmon (Salmo salar): gross, histological and biochemical deficiency signs. J Nutr 106, 892-904.

15. Bell JG, Cowey CB, Adron JW, et al. (1987) Some effects of selenium deficiency on enzyme activities and indices of tissue peroxidation in Atlantic salmon parr (Salmo salar). Aquaculture 65, 43-54.

16. Watanabe T, Takeuchi T, Wada M, et al. (1981) The relationship between dietary lipid levels and $\alpha$-tocopherol requirement of rainbow trout. Bull Jap Soc Sci Fish 47, 1463-1471.

17. Cowey CB, Adron JW, Walton MJ, et al. (1981) Tissue distribution, uptake and requirement for $\alpha$-tocopherol of rainbow trout (Salmo gairdneri) fed diets with a minimal content of unsaturated fatty acids. J Nutr 111, 1556-1567.

18. Cowey CB, Adron JW \& Youngson A (1983) The vitamin E requirement of rainbow trout (Salmo gairdneri), given diets containing polyunsaturated fatty acids derived from fish oil. Aquaculture 30, 85-93.

19. Hamre $K \&$ Lie $\varnothing$ (1995) Minimum requirement of vitamin $E$ for Atlantic salmon, Salmo salar, at startfeeding. Aquac Res 26, $175-184$

20. Christiansen R, Glette J \& Lie Ø (1995) Antioxidant status and immunity in Atlantic salmon (Salmo salar L.) fed semipurified diets with and without astaxanthin supplementation. J Fish Dis 18, 317-328.

21. Thelin B, Lundstedt T, Seifert E, et al. (1996) Fors $\varnothing$ ksplanlegging og optimering for experimentalisten (Experimental planning and optimisation for the researcher). In Anvendelse av Kjemometri innen Forskning og Industri (Application of Chemometrics in Research and Industry), pp. 81-106 [R Nortvedt, F Brakstad and OM Kvalheim, et al., editorss]. Bergen, Norway: Tidsskriftforlaget Kjemi AS.

22. Hamre K, Christiansen R, Waagbø R, et al. (2004) Supplementation of antioxidant vitamins, minerals and polyunsaturated lipids to Atlantic salmon (Salmo salar, L.) - effects on growth performance and fillet quality. Aquac Nutr 10, 113-123.

23. Lygren B, Hamre K \& Waagbø R (1999) Effects of dietary proand antioxidants on some protective mechanisms and health parameters in Atlantic salmon. J Aquat Anim Health 11, 211-221.

24. Waagbø R, Hamre K, Bjerkås E, et al. (2003) Cataract formation in Atlantic salmon, Salmo salar L., smolt relative to dietary pro- and antioxidants and lipid level. J Fish Dis 26, 213-229.

25. Torstensen B, Lie $\varnothing \&$ Hamre K (2001) A factorial experimental design for investigation of effects of dietary lipid content and pro- and antioxidants on lipid composition in Atlantic salmon (Salmo salar) tissues and lipoproteins. Aquac Nutr 7, 265-276.

26. National Research Council (1993) Nutrient requirements of fish. In Nutrient Requirements of Domestic Animals, pp. 62-63. Washington, DC: National Academy Press.

27. Box GEP, Hunter WG \& Hunter JS (1978) Statistics for Experimenters. An Introduction to Design, Data Analyses and Model Building. New York: Wiley.

28. Langsrud Ø, Ellakjær MR \& Næs T (1994) Identifying significant effects in fractional factorial experiments. J Chemom $\mathbf{8}$, $205-219$.
29. Sundberg R (1994) Interpretation of unreplicated two-level factorial experiments, by examples. Chemom Intell Lab Syst 24, $1-17$.

30. Lie Ø, Sandvin A \& Waagb $\varnothing$ R (1994) Transport of $\alpha$-tocopherol in Atlantic salmon (Salmo salar) during vitellogenesis. Fish Physiol Biochem 13, 241-247.

31. Mæland A \& Waagbø R (1998) Examination of the qualitative ability of some cold water marine teleosts to synthesise ascorbic acid. Comp Biochem Physiol 121, 249-255.

32. Torrissen OJ (1986) Pigmentation of salmonids - a comparison of astaxanthin and canthaxanthin as pigment source for rainbow trout. Aquaculture 53, 271-278.

33. Lie Ø, Waagb $\varnothing \mathrm{R} \&$ Sandnes K (1988) Growth and chemical composition of adult Atlantic salmon (Salmo salar) fed dry and silage based diets. Aquaculture 69, 343-353.

34. Liaset B, Julshamn K \& Espe M (2003) Chemical composition and theoretical nutritional evaluation of the produced fractions from enzymic hydrolysis of salmon frames with Protamex (TM). Process Biochem 38, 1747-1759.

35. Hamre K, Næss T, Espe M, et al. (2001) A formulated diet for Atlantic halibut (Hippoglossus hippoglossus, L.) larvae. Aquac Nutr 7, 123-132.

36. Svardal AM, Mansoor MA \& Ueland PM (1990) Determination of reduced, oxidised and protein-bound glutathione in human plasma with pre column derivatisation with monobromobimane and liquid chromatography. Anal Biochem 184, $338-346$

37. Lang JK, Gohil K \& Packer L (1986) Simultaneous determination of tocopherols, ubiquinols and ubiquinones in blood, plasma, tissue homogenates and subcellular fractions. Anal Biochem 157, 106-116.

38. Podda M, Weber C, Traber MG, et al. (1996) Simultaneous determination of tissue tocopherols, tocotrienols, ubiquinols, and ubiquinones. J Lipid Res 37, 893-901.

39. Hoffman A, Spetner LM \& Burke M (2008) Ramifications of a redox switch within a normal cell: its absence in a cancer cell. Free Radic Biol Med 45, 265-268.

40. Kemp M, Go Y-M \& Jones DP (2008) Nonequilibrium thermodynamics of thiol/disulfide redox systems: a perspective on redox systems biology. Free Radic Biol Med 44, 921-937.

41. Rebrin I, Rajindar S \& Sohal RS (2008) Pro-oxidant shift in glutathione redox state during aging. Adv Drug Deliv Rev 60, 1545-1552.

42. Dalle-Donne I, Rossi R, Giustarini D, et al. (2007) S-glutathionylation in protein redox regulation. Free Radic Biol Med $\mathbf{4 3}$, 883-898.

43. Krzywanski DM, Dickinson DA, Iles KE, et al. (2004) Variable regulation of glutamate cysteine ligase subunit proteins affects glutathione biosynthesis in response to oxidative stress. Arch Biochem Biophys 423, 116-125.

44. Renner A, Sagstetter MR, Gotz ME, et al. (2004) Heterotopic rat heart transplantation: severe loss of glutathione in 8-hour ischemic hearts. $J$ Heart Lung Transplant 23, 1093-1102.

45. Vegusdal A, Gjøen T, Berge RK, et al. (2005) Effect of $18: 1 n-9, \quad 20: 5 n-3$ and $22: 6 n-3$ on lipid accumulation and secretion by Atlantic salmon hepatocytes. Lipids $\mathbf{4 0}$, 477-486.

46. Berntssen MHG, Lundebye A-K \& Maage A (1999) Effects of elevated copper concentrations on growth, feed utilisation and nutritional status of Atlantic salmon (Salmo salar L.) fry. Aquaculture 174, 167-181.

47. Berntssen MHG, Hylland K, Wendelar Bonga SE, et al. (1999) Toxic levels of dietary copper in Atlantic salmon (Salmo salar) parr. Aquat Toxicol 46, 87-99.

48. Andersen F, Lorentzen M, Waagb $\varnothing$ R, et al. (1997) Bioavailability of different forms of iron in Atlantic salmon (Salmo salar) smolts. Aquac Nutr 3, 239-246. 
49. Maage A, El-Mowafi AFA \& Lygren B (2000) Manganese requirement of Atlantic salmon (Salmo salar) during start feeding. Fisheries Sci 66, 1-8.

50. Bjerkeng B, Hamre K, Hatlen B, et al. (1999) Astaxanthin deposition in fillets of Atlantic salmon Salmo salar L. fed two dietary levels of astaxanthin in combination with three levels of $\alpha$-tocopheryl acetate. Aquac Res 30, 637-646.

51. Hillestad M \& Johnsen F (1994) High-energy low-protein diets for Atlantic salmon - effects on growth, nutrient retention and slaughter quality. Aquaculture 124, 109-116.
52. Åsnes ER (2006) Optimal makronæringsstoffsammensetning i fôr til torskeyngel (Gadus morhua L.) og effekt av pepsin-prehydrolysert protein i fôr på vekst og overlevelse (Optimal macronutrient composition in feed for cod (Gadus morhua L.) juveniles and effect of pepsin-prehydrolysed protein in feed on growth and survival). Masters Thesis, Department of Biology, University of Bergen, Norway.

53. Hamre K, Bæverfjord G \& Harboe $\mathrm{T}$ (2005) Macronutrient composition of formulated diets for Atlantic halibut (Hippoglossus hippoglossus, L.) juveniles II: protein:lipid levels at low carbohydrate. Aquaculture 244, 283-291. 